広島県の主要産地（江田島市，竹原市）における絶滅危惧種カブトガニの 生息状況

\title{
Occurrence of endangered tri-spine horseshoe crab in Etajima and Takehara Cit- ies of Hiroshima Prefecture, western Japan
}

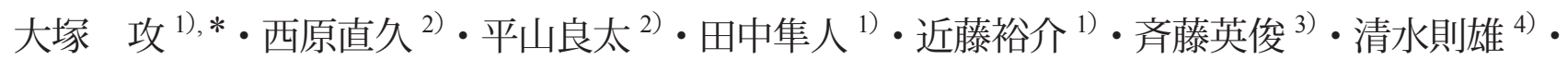
富川 光 ${ }^{5)}$ ・飯田 健 ${ }^{1)}$ ・米谷まり ${ }^{1)}$

${ }^{1)}$ 広島大学大学院生物圈科学研究科附属瀬戸内圈フィールド科学教育研究センター竹原ステーション。 $\bar{T} 725-0024$ 竹 原市港町 5-8-1

${ }^{2)}$ 大柿自然環境体験学習交流館「さとうみ科学館」＝７37-2214 江田島市大柿町深江 1073-1

${ }^{3)}$ 広島大学大学院生物圈科学研究科。 T 739-8528 東広島市鏡山 1-4-4

4)広島大学総合博物館. $7739-8524$ 東広島市鏡山 1-1-1

${ }^{5)}$ 広島大学大学院教育学研究科. $\bar{T} 739-8524$ 東広島市鏡山 1-1-1

Susumu OHTSUKA ${ }^{1)}$,* , Naohisa NISHIHARA ${ }^{2)}$, Ryota HIRAYAMA ${ }^{2)}$, Hayato TANAKA ${ }^{1)}$, Yusuke KONDO ${ }^{1)}$, Hidetoshi SAITO ${ }^{3)}$, Norio SHIMIZU ${ }^{4)}$, Ko TOMIKAWA ${ }^{5)}$, Ken IIDA ${ }^{1)}$ and Mari YONETANI ${ }^{1)}$

1) Takehara Station, Setouchi Field Science Center, Graduate School of Biosphere Science, Hiroshima University, 5-8-1 Minatomachi, Takehara, Hiroshima 725-0024, Japan

2) Satoumi Science Museum, 1073-1 Fukae, Ogaki-cho, Etajima, Hiroshima 737-2214, Japan

3) Graduate School of Biosphere Science, Hiroshima University, 1-4-4 Kagamiyama, Higashi-Hiroshima, Hiroshima 739-8528, Japan

4) Hiroshima University Museum, 1-1-1 Kagamiyama, Higashi-Hiroshima 739-8524, Japan

5) Graduate School of Education, Hiroshima University, 1-1-1 Kagamiyama, Higashi-Hiroshima, Hiroshima 739-8524, Japan

\begin{abstract}
The tri-spine horseshoe crab Tachypleus tridentatus is considered at risk and has been granted protection in Japan at least since the 1990s. The breeding areas in Okayama, Ehime and Saga prefectures, Japan, are protected by national and local laws, while in Hiroshima Prefecture the species has not been officially conserved by local administrations. However, its breeding has long been noticed at two sites there: Etajima and Takehara cities. We compiled data on the habitat of these two populations, using published literature, inquiries to the public, and our own research from 1999 to 2016. During the period of our investigation, breeding at Etajima City was observed only once, in July 2000. In Takehara City, a distinct recruitment of juveniles has been observed since 2015. The compiled data on this horseshoe crab in Hiroshima Prefecture confirms that juveniles up to the tenth-instar stage inhabit the mud flats and that adults appear in the habitat only during the summer, as similarly observed for populations in other regions of Japan. The Takehara population was genetically characterized with the AT-rich region of mitochondrial DNA by only one haplotype, inferring that the Seto Inland Sea populations exhibit the founder effect.
\end{abstract}

Key Words: conservation, Etajima, Hiroshima, horseshoe crab, genetic diversity, Tachypleus tridentatus, Takehara

\section{はじめに}

生きた化石としてよく知られるカブトガニ Tachypleus tridentatus（Leach, 1819）は世界に現生するカブトガニ類 4 種のうちの 1 種で, 東アジア〜東南アジアにかけて広く分

Received 29 August 2016 Accepted 22 March 2017

* Corresponding author

E-mail: ohtsuka@hiroshima-u.ac.jp
布する（関口 1984, 1991, 1993; 牢路 2015）。本種はカブト ガニ類では最大種で, メスはオスより大型で全長 $60 \mathrm{~cm}$ に も達する（牢路 2015）。日本では，1920 年〜1930 年代ま では瀬戸内海全域〜九州北部において広く分布していたも のの, 1990 年代〜現在にかけて各地の個体群は絶滅して しまい（関口 1991, 1993; 和田ら 1996; 日野 2008; 惣路 2015), 岡山県, 広島県, 山口県, 大分県, 福岡県, 佐賀 県, 長崎県のごく限られた海域に生息するまでに激減した (関口 1993; 日野 2008; 䓤路 2015). 環境省の選定する絶滅 危惧 I 類に評価されており（環境省 2015）, 特に瀬戸内海 
個体群の絶滅が危惧されている（日本ベントス学会 2012). 1930 年には徳島県, 香川県, 愛媛県に分布し, 1950 1960 年代では大阪府, 兵庫県でも確認されていた （関口 1993; 日野 2008; 惣路 2015）。長崎県を除いて全県で 絶滅危惧が最も懸念される絶滅危惧 I 類ないしは IA 類と してランク付けがされている。国が繁殖地を天然記念物に 指定しているのは岡山県笠岡市（生江浜海岸は1928 年指 定, 1994 年指定解除. 神島水道は 1971 年追加指定), 佐 賀県伊万里市（2015 年指定）の 2 箇所である（関口 1991, 1993; 惣路 2015). 愛媛県では西条市の繁殖地を 1949 年に 県の天然記念物に指定している（愛媛県 2014）. 長崎県で は2009年の条例指定により種そのものを保護している (長崎県 2011). しかし, 広島県, 山口県, 福岡県では法 的な保全措置が取られていない.

日本では 1920 年代からその学術的価值が指摘されてい たが, 生物多様性の重要性が近年になってようやく一般市 民にも再認識されるまではカブトガニにとって受難の時代 が続いたと言える.カブトガニの個体数減少の原因は, カ ブトガニの生活, 䬣場, 繁殖の場を破壊し続けたことが大 きな原因である（関口 1991, 1993; 中国新聞「新せとうち 学」取材班 1998; 加藤 1999; 日野 2008; 惣路 2015). 過去 には農業用肥料に利用されたり，家畜の餌料などに利用さ れたり, 戦後食糧難のころは食用として地域的に利用され たこともあるとされる（関口 1991; 伊藤・伊藤 2009）. 密 度の高い海域では漁網などを破ることから漁師に疎まれて 殺されている（関口 1991, 1993; 制路 2015）.

近年, 干潟のシンボリックな希少生物であることや生物 多様性保全あるいは応用医学の観点から, 国内のカブトガ 二研究も活発である. 特に大分県守江湾, 福岡県中津湾, 岡山県笠岡市における研究が多い.カブトガニの産卵場や 幼生・幼体・成体の分布と物理環境との関連（清野ら 1998a, b, 2000, 2002, 2007; 前田ら 2000; 清野 2001; 和田ら 2010; 信田ら 2012; Wada et al. 2016), 行動（清野ら 1999; 渡辺ら 2013; 渡辺 2014; Wada et al. 2016), 保全方法の提言 （清野・宇高 2001; 清野ら 2002, 2004; 日野 2008), 個体群 の遺伝的特徴（Nishida \& Koike 2009）などがある.また, カブトガ二類の血液が細菌類の内毒素への反応, 所謂

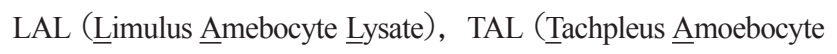
Lysate）などの遺伝子レベルでの機構の詳細な研究なども 行われている（例えば, Kawabata et al. 2009）.

広島県では, 広島県レッドデータブック初版（広島県 1995）でカブトガニは希少種と位置づけられ，改訂された 2003 年版（広島県 2004），2011 年版（広島県 2012）では 環境省のカテゴリーに準じて絶滅危惧 I 類と分類されてい る. 初版では生息地として, 松永湾, 生口島, 竹原市, 江 田島湾が挙げられている。しかし，2003 年版では幼体の 確実な生息地としては江田島湾のみとなり，1994 年には 竹原市で産卵が確認されたが恒常的ではないとされてい る。また, 県内の代表的な産卵場であった江田島湾では,
2000 年以降産卵および雌雄つがいの来遊は確認されてい ない（西原 2007; 平山・西原 2008, 2009）。一方，竹原市 八チ干潟（別名 ハチの干潟）では 2005 年以降（ハチ干潟 調査隊 2016）からカブトガニの目撃が散発している.

広島県におけるカブトガニの出現報告は断片的であり, 十分な調査も実施されてこなかった。本稿では，広島県に おいて主要な生息地とされる江田島市および竹原市（広島 県 2012）におけるカブトガニの最新の生息状況を経時的 に報告する。また, 竹原市八チ干潟の個体群については遺 伝子情報を瀬戸内海の他海域〜九州北岸に生息する個体群 と比較した，著者らは, 本調査がカブトガニの生態を理解 するための基礎的データを提供するだけでなく，今後の保 全政策の一助となることを望む.

\section{材料と方法}

\section{江田島市における生息状況}

江田島湾は面積約 1,200 ha, 干潮時には約 33.2 ha の干潟 ができ（中国経済産業局 2005），それに隣接した砂浜，小 規模ではあるが 10 余りの河川が湾内に流入するなど，カブ トガニの生息条件を満たした場所である（䊍路 2015）．江田 島湾の干潟におけるカブトガニ生息状況を明らかにするた め, 江田島湾最奥部の江南干潟において 2000 年 9 月, 2005 年 9 月，および長瀬干潟において 2006〜2016 年 3〜10月に おける日中の大潮干潮時刻の 1 2 時間前から干潮時刻まで の間に生息調査および観察会を実施し，目視で確認した個 体をカウントした (Fig. 1). また，大杮自然環境体験学習交 流館「さとうみ科学館」において，その前身の事業である $「 大$ 柿町海辺の生き物調査団」の時期を含め, カブトガニ調 査を含む広報活動としてニュースレターを 2000 年以降毎月 1〜2 回発行してきており, 江田島市内の小中学校, 公民館 および漁業協同組合などに配布してきた。本調査において，



Fig. 1. Study sites of the tri-spine horseshoe crab Tachypleus tridentatus in Hiroshima Prefecture, western Japan. 
ニュースレターによってカブトガニ調査を知った江田島市 民や漁業従事者から本種の情報が入るようになってきたた め, 実際に確認できた個体については捕獲された日時, 場 所および方法などの情報をデータとして含めた. 生息調査 や観察会において確認拉よび市民や漁業従事者から情報提 供されたカブトガニは, 脱皮中の生体以外は実験室に持ち 帰り, 生体, 死骸および脱皮殼の状態, 前体幅長および外 部形態（前体の前縁, 歩脚, 後体の縁棘）を記録し, 生体 および死骸には個体番号を付けた。また，カブトガニは, 外部形態の特徵により,「幼体」と「成体（オス・メス）」 を判別することができる。本調査では惣路（2015）に従い， 最終脱皮を終えた「成体」の場合，オスは前体前縁に一対 のくぼみを持ち, 後体の長い縁棘は 6 対であるが, メスは 前体前縁にくぼみはなく, 後体の長い縁棘は 3 対であり, 残りは短いという特徵を持つ。 また, 成体オスの場合, 第 1 ・第 2 歩脚の先端は八サミではなく, 鉤爪のついた把持器 になっている，「幼体」の場合，前体前縁部は成体メス（く ぼみがない), 後体縁棘は成体才ス（縁棘は 6 対）にみられ る特徴をあわせもつことによって判断した。成長段階別の 脱皮齢数と体サイズの関係については, 既往文献では飼育 条件下でのデータに基づいており（たとえば関口 1984; 川原 1984), 野外ではとくに成体サイズに近づくにしたがい個体 による成長のバラツキが大きくなると思われる. 本研究に おける脱皮齢数は, 関口（1984）による前体幅長との関係 から推定しているが, 各脱皮齢の境界となるような個体に ついては, 前体幅長以外の前体部や後体部の長さも参考に して慎重に判断した．個体情報を記録した生体には標識と して捕獲日および個体番号の明記されたプラスチック製の テープを前体部背面に瞬間接着材で貼り付けた後, 再び江 田島湾に放流し, 再捕獲状況を記録した。

さらに, カブトガニの繁殖状況を確認するために, 江田 島湾最奥部の長瀬干潟および江南干潟において 2000〜 2016 年 7 9 月の大潮の前後数日間の夜間の満潮時刻の 1〜2 時間前から満潮時刻までの間をライトで照らしなが ら目視調查を行った（Fig. 1).

なお，これまでカブトガニの成体より若い個体が幼生（亜 成体を除く）と呼ばれていたが（例えば，関口（1984）， 1 脱皮齢は「幼生」, それ以降は「幼体」と呼ぶことが節 足動物学的には正しい. 本稿ではこの考えを踏襲した。

\section{竹原市における生息状況}

竹原市八チ干潟（Fig. 1）は竹原市竹原町南に位置する 河口干潟で面積が約 22 ha である (ハチ干潟調査隊 2016). 広島藩が竹原港の土砂による埋没を防ぐことと塩田開発の ために賀茂川の流路を 1742 年から 32 年間の工期をかけて 現在の位置に河口を変更し（「賀茂川の瀬替え」と呼ばれ る）(竹原市 2015), それ以降の河川と海の相互作用に よってハチ干潟が形成されていった。

竹原市八チ干潟潮間帯において, 2015 年 9 月 13 日（調
查参加人数: 3 名: 広島大学大学院生物圈科学研究科附属 瀬戸内圈フィールド科学教育研究センター竹原ステーショ ン (以後, 竹原ステーションと略) 所属教員・学生), 14 日 （3名：竹原ステーション所属教員・学生）および 2016 年 2 月 25 日 (7名: 竹原ステーション所属教員・学生), 4 月 22 日（8名：竹原ステーション所属教員・学生）に幼 体の有無, 密度, 成長段階組成を調查した. 2015 年 9 月 にはカブトガニの生息密度は, カブトガニが生息したおお よその場所を Google earth（version 7.1.5.1557）の距離測定 ツールを使って正方形とみなして面積を求め, その場所で 確認した全個体数を除して算出した。より正確な密度を算 出するために, 2016 年 4 月 22 日には生息密度を算出する ために携帯用 GPS (m-241, Holux Technology, Inc.) を用い て生息域外周を測定し，その範囲の中で目視観察できる全 個体を採取した。採取した個体の全長, 前体幅長をノギス で測定後, 電子天科 (PB602-S, Mettler-Toledo International Inc.）で湿重量を現場で測定した。測定後は元の生息場所 へ放流した. 2015 年 9 月と 2016 年 4 月に測定したカブト ガニの前体幅長, 湿重量については有意水準 $\alpha=0.05$ とし, R software（version 3.0.1）を用いて Mann-Whitney $U$-testに よって平均值を比較した。また， 2015 年 9 月と 2016 年 4 月に観察したカブトガニについて成長段階組成（関口 （1984）による 1〜17 脱皮齢を識別）を比較するために jsSTAR（version 2.9.9）により $\chi^{2}$ 検定および残差分析を行っ た. 2015 年 9 月および 2016 年 4 月の観測日以外に, カブ トガニの幼体及び成体の出現の確認（個体サイズ, 生息密 度の測定は実施していない）は，2015 年 7 月 31 日（48 名：賀茂川流域環境保全事業参加者)，2016 年 7 月 21 日 (3 名: 竹原ステーション所属教員・学生), 8 月 5 日（6 名: 竹原ステーション所属教員・学生) に同場所で行っ た。また，生息環境の調査として幼体の生息地 2 地点にお いて, 表層から深さ約 $3 \mathrm{~cm}$ までの底質を約 $150 \mathrm{ml}$ 採取し た. 採取した底質は乾燥オーブン（FS-405, Advantec, Inc.) を $120^{\circ} \mathrm{C}$ に設定して 3 日間かけて乾燥後, 直径が 4.000 , $2.000,1.000,0.500,0.250,0.125 \mathrm{~mm}$ のろるい用いて 粒度を測定し, 中央粒径值を算出した。

竹原市で発見されたカブトガニ成体には外部共生生物が 見られたが,これらは西村（1995），Chan et al. (2009）を 参照して同定した.

\section{竹原市の個体群の遺伝的特徵}

2016 年 4 月 22 日の調查で竹原市八千干潟潮間帯から得 られた 10 個体（前体幅長 $3.96 \sim 4.40 \mathrm{~cm}$ の幼体）の後体縁 棘からそれぞれ約 $1 \mathrm{~mm}$ 角の組織を採取し, DNA 抽出を 行った. DNA 抽出にはDNeasy Blood and Tissue Kit (Qiagen, USA）を用い, 方法はキット推奨のプロトコルに従っ た. PCR 反応液は, KOD FX Neo（TOYOBO, 大阪） $0.5 \mu \mathrm{L}, 2 \times$ Buffer for KOD FX Neo $12.5 \mu \mathrm{L}, 2 \mathrm{mM}$ dNTP $5 \mu \mathrm{L}$ ，プライマー (Forward, Reverse) 各 $1 \mu \mathrm{L}(5 \mathrm{pmol})$, 滅 
菌蒸留水 $4 \mu \mathrm{L}, \mathrm{DNA}$ テンプレート $1 \mu \mathrm{L}$ の計 $25 \mu \mathrm{L}$ とした. プライマーは, Nishida \& Koike (2009) によってミトコ ンドリア遺伝子の AT リッチ反復配列部分をターゲットに 設計された HC-mt12s1.hc (5'-GTCTAACCGCGGTAGCTGGCACAATTTTG-3') と HC-mtRGln1.he (5'-TTTTTAGTGTAAAGGCACATTGAATTTTG-3') を用いた。 また, PCR 条件 はNishida \& Koike（2009）に従った. 得られたPCR 産物 は FastGene Gel/PCR Extraction Kit（日本ジェネティクス, 東京）を用いて精製した後, DNA 塩基配列解析サービス (マクロジェン・ジャパン, 京都) に委託して塩基配列を 決定した.

Nishida \& Koike（2009）は, 北九州〜瀬戸内海西部に生 息しているカブトガニの個体群の遺伝的集団構造をミトコ ンドリア遺伝子の AT リッチ反復配列部分（369 bp）を用い て解析し，認識した計７ハプロタイプをそれぞれ AT1〜 AT7 とした. 本研究では, 竹原市八チ干潟産のカブトガニ が AT1〜AT7 と同一かもしくは他のハプロタイプをもつの かどうかを調べた。
なおこれらの個体については組織採取後, 傷口を 99.5\%エタノールで消毒して経過を 30〜8 日間みたが, 死亡する個体はなかった。

\section{結 果}

\section{江田島市における生息状況}

江田島では，1999～2016年の調査期間に脱皮中の 4 個体を除く 77 個体を採集した（Fig. 2; Table 1). 年別に みると，2006 年までにカブトガニの生息が確認されたの は，沖合の漁網に掛かった計 13 個体であり，潮干狩りや 海水浴客による干潟での確認例は 1 個体のみであった. 2007 年と 2008 年は確認例が多く, 干潟における生息調査 や観察会によって計 47 個体が見つかったほか, 潮干狩り や海水浴客によって計 4 個体，漁網に掛かった計 3 個体が 確認された．2009～2016年の期間は，カブトガニの確認 例が少なく，長瀬干潟における生息調査や海水浴客そして 江南干潟における潮干狩り客によって計 5 個体, および漁

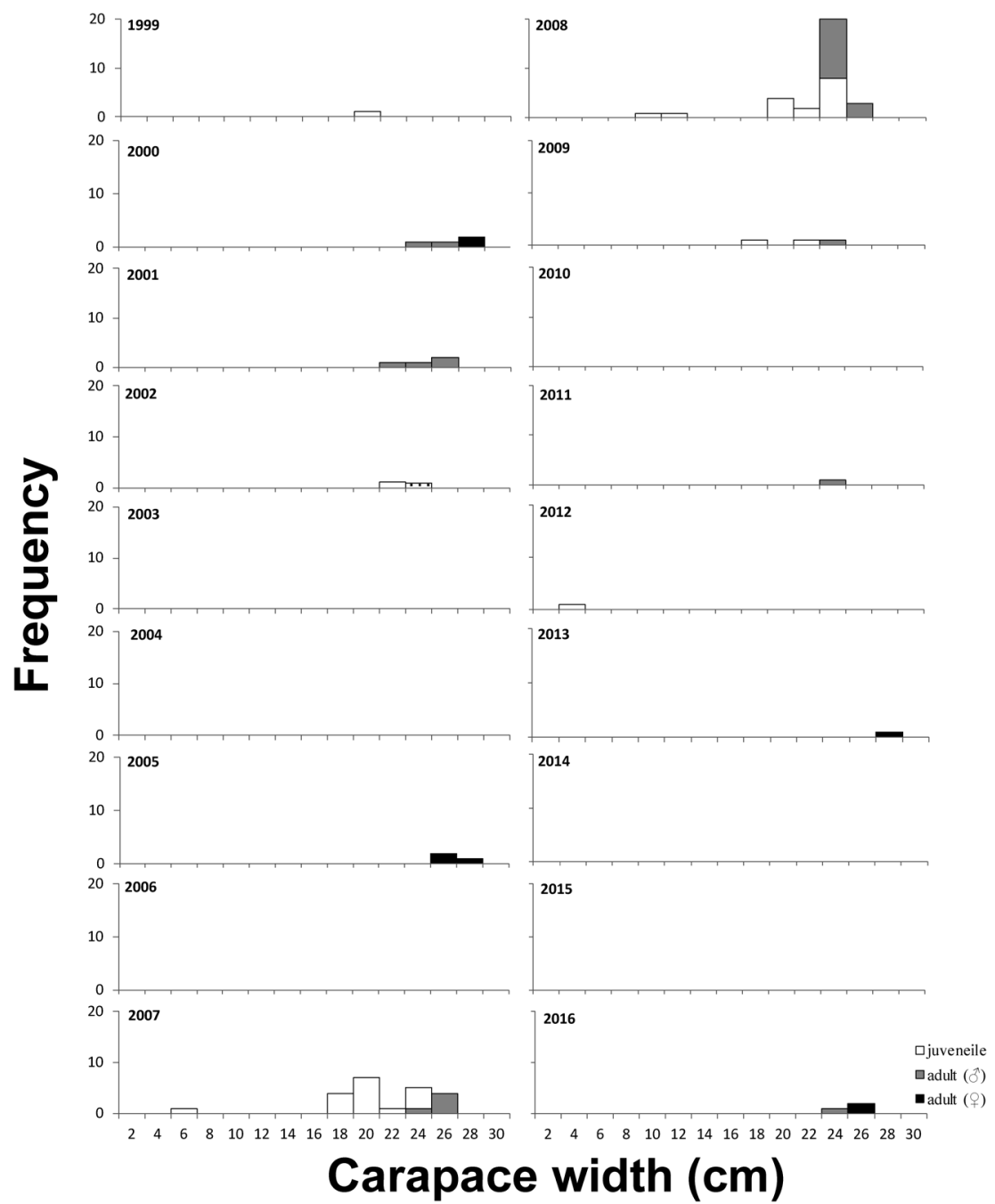

Fig. 2. Composition of carapace width of the tri-spine horseshoe crab Tachypleus tridentatus collected from Etajima Bay, Etajima City, Hiroshima Prefecture during 1999 to 2016. 
大塚 攻・西原直久・平山良太・田中隼人・近藤裕介・斉藤英俊・清水則雄・富川 光・飯田 健・米谷まり

Table 1. Collection data of tri-spine horseshoe crab Tachypleus tridentatus collected from Etajima City.

\begin{tabular}{|c|c|c|c|c|c|c|c|c|}
\hline \multirow{3}{*}{$\begin{array}{c}\text { Collection } \\
\text { year }\end{array}$} & \multirow{3}{*}{ Collection methods ${ }^{* 1}$} & \multirow{3}{*}{$\begin{array}{c}\text { Total number } \\
\text { of } \\
\text { investigations }\end{array}$} & \multirow{3}{*}{$\begin{array}{c}\text { Mean number } \\
\text { of } \\
\text { investigators }\end{array}$} & \multicolumn{5}{|c|}{ Number of horseshoe crabs } \\
\hline & & & & \multicolumn{2}{|c|}{ Live } & \multicolumn{2}{|c|}{ Dead } & \multirow{2}{*}{ Exuviae } \\
\hline & & & & Juvenile & Adult & Juvenile & Adult & \\
\hline 1999 & Offshore collecting by fisherman & 1 & 1 & 1 & 0 & 0 & 0 & 0 \\
\hline \multirow[t]{3}{*}{2000} & Offshore collecting by fisherman & 3 & 1 & 0 & 3 & 0 & 0 & 0 \\
\hline & $\begin{array}{l}\text { Intertidal collecting by clam digger, } \\
\text { sea bather or citizen }\end{array}$ & 1 & 1 & 0 & 1 & 0 & 0 & 0 \\
\hline & Intertidal observation meeting ${ }^{* 2}$ & 1 & 41 & 0 & 0 & 0 & 0 & 0 \\
\hline 2001 & Offshore collecting by fisherman & 7 & 1 & 0 & 8 & 0 & 0 & 0 \\
\hline 2002 & Offshore collecting by fisherman & 4 & 1 & 2 & 2 & 0 & 0 & 0 \\
\hline 2003 & No collecting & 0 & 0 & 0 & 0 & 0 & 0 & 0 \\
\hline 2004 & $\begin{array}{l}\text { Intertidal collecting by clam digger, } \\
\text { sea bather or citizen }\end{array}$ & 1 & 6 & 0 & 0 & 0 & 1 & 0 \\
\hline \multirow[t]{3}{*}{2005} & Offshore collecting by fisherman & 4 & 1 & 0 & 4 & 0 & 0 & 0 \\
\hline & $\begin{array}{l}\text { Intertidal collecting by clam digger, } \\
\text { sea bather or citizen }\end{array}$ & 1 & 1 & 0 & 0 & 0 & 0 & 1 \\
\hline & Intertidal observation meeting ${ }^{* 2}$ & 1 & 19 & 0 & 0 & 0 & 0 & 0 \\
\hline 2006 & Intertidal observation meeting & 1 & 15 & 0 & 0 & 0 & 0 & 18 \\
\hline \multirow[t]{3}{*}{2007} & $\begin{array}{l}\text { Intertidal collecting by clam digger, } \\
\text { sea bather or citizen }\end{array}$ & 4 & 3 & 2 & 0 & 0 & 0 & 3 \\
\hline & Intertidal observation meeting & 4 & 24 & 10 & 1 & 0 & 0 & 0 \\
\hline & Intertidal sampling & 9 & 1 & $4^{* 3}$ & 4 & 2 & 0 & 21 \\
\hline \multirow[t]{4}{*}{2008} & Offshore collecting by fisherman & 2 & 1 & 1 & 3 & 0 & 0 & 0 \\
\hline & $\begin{array}{l}\text { Intertidal collecting by clam digger, } \\
\text { sea bather or citizen }\end{array}$ & 3 & 1 & 2 & 0 & 1 & 0 & 0 \\
\hline & Intertidal observation meeting & 1 & 14 & 0 & 2 & 0 & 0 & 0 \\
\hline & Intertidal sampling & 18 & 1 & 19 & 14 & 3 & 0 & 4 \\
\hline \multirow[t]{4}{*}{2009} & Offshore collecting by fisherman & 4 & 1 & 2 & 2 & 0 & 0 & 0 \\
\hline & $\begin{array}{l}\text { Intertidal collecting by clam digger, } \\
\text { sea bather or citizen }\end{array}$ & 2 & 1 & 1 & 1 & 0 & 0 & 0 \\
\hline & Intertidal observation meeting & 1 & 15 & 0 & 0 & 0 & 0 & 0 \\
\hline & Intertidal sampling & 10 & 3 & 2 & 3 & 0 & 0 & 1 \\
\hline 2010 & Intertidal sampling & 12 & 1 & 0 & 0 & 0 & 0 & 1 \\
\hline \multirow[t]{3}{*}{2011} & Offshore collecting by fisherman & 3 & 1 & 0 & 2 & 0 & 1 & 0 \\
\hline & $\begin{array}{l}\text { Intertidal collecting by clam digger, } \\
\text { sea bather or citizen }\end{array}$ & 1 & 5 & 0 & 1 & 0 & 0 & 0 \\
\hline & Intertidal sampling & 10 & 1 & 0 & 0 & 0 & 0 & 0 \\
\hline \multirow[t]{2}{*}{2012} & Offshore collecting by fisherman & 1 & 1 & 0 & 0 & 0 & 0 & 1 \\
\hline & Intertidal sampling & 4 & 2 & 1 & 0 & 0 & 0 & 0 \\
\hline \multirow[t]{2}{*}{2013} & $\begin{array}{l}\text { Intertidal collecting by clam digger, } \\
\text { sea bather or citizen }\end{array}$ & 1 & 1 & 0 & 0 & 0 & 1 & 0 \\
\hline & Intertidal sampling & 6 & 3 & 0 & 0 & 0 & 0 & 0 \\
\hline 2014 & Intertidal sampling & 6 & 2 & 0 & 0 & 0 & 1 & 0 \\
\hline 2015 & Intertidal sampling & 4 & 3 & 0 & 0 & 0 & 0 & 0 \\
\hline \multirow[t]{2}{*}{2016} & Offshore collecting by fisherman & 3 & 1 & 0 & 3 & 0 & 0 & 0 \\
\hline & Intertidal sampling & 19 & 1 & 0 & 0 & 0 & 0 & 0 \\
\hline
\end{tabular}

*1 Intertidal collecting by clam digger was done at Kounan, and other intertidal data were obtained from Nagase, excluding intertidal observation meeting in 2000 and 2005 .

*2 Intertidal observation meeting was done at Kounan in 2000 and 2005.

*3 Four individuals were under exuviation.

業従事者の情報提供により漁網に掛かった計 4 個体が確認 された。

確認されたカブトガニは, 外部形態によって幼体 40 個 体（前体幅長：3.5 24.7 cm), 成体オス 29 個体（前体幅 長：21.0 25.0 cm）抢よび成体メ久 8 個体（前体幅長： $24.0 \sim 26.5 \mathrm{~cm}$ ）に区分された（Fig. 2). 前体幅長 $10.5 \mathrm{~cm}$ 以下の幼体は 4 個体と少なかったが, このうち前体幅長
$5.1 \mathrm{~cm}$ の個体は 2007 年 5 月 1 日, 前体幅長 $8.1 \mathrm{~cm}$ の個体 は 2008 年 4 月 6 日および $10.5 \mathrm{~cm}$ の個体は 2008 年 4 月 8 日にそれぞれ江南干潟における潮干狩り客によって発見さ れた。また, 最も小型の前体幅長 $3.5 \mathrm{~cm}$ の個体は 2012 年 8月 31 日に確認された。 また, 前体幅長から脱皮齢数を 推定すると, 江田島湾で確認されたカブトガニは 8〜 17 脱 皮齢に相当した（Fig. 3). 


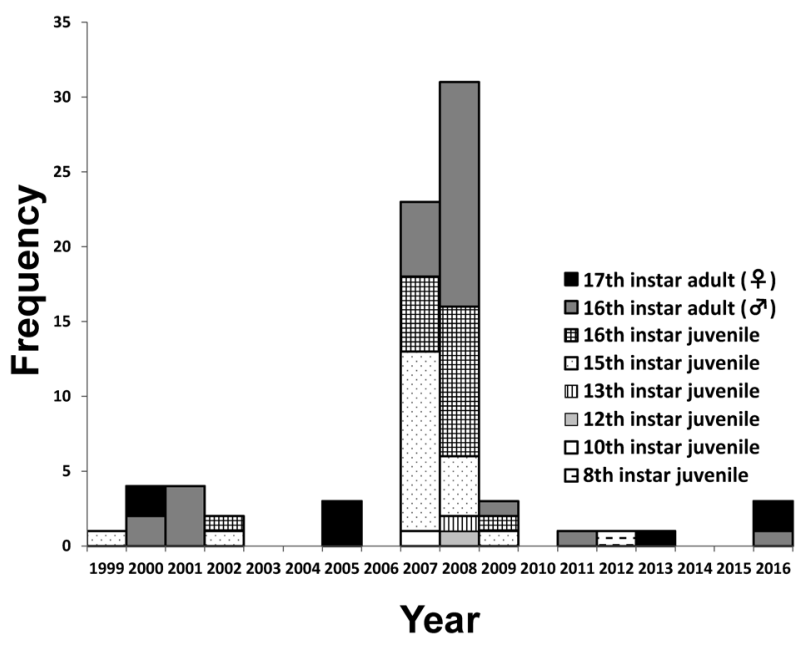

Fig. 3. Composition of individual instars of the tri-spine horseshoe crab Tachypleus tridentatus collected from Etajima Bay, Etajima City, Hiroshima Prefecture during 1999 to 2016. Instars defined by Sekiguchi (1984).

2016 年に確認された 3 個体を除くカブトガニの生体 74 個体に標識を貼り付けて再び江田島湾に放流した結果, 20 個体がのべ 53 回再捕獲された（Table 2). 再捕獲された個 体はすべて湾内での記録であり, 湾外からの発見例はな かった。再捕獲日については，湾の沖合では 5〜 7月およ び 9〜11月，長瀬干潟では 5〜8月に集中していた. 最も 再捕獲された期間が長かったNo. 37 の個体は, 2007 年 9 月 27 日に長瀬干潟で成体オス（前体幅長 $23.0 \mathrm{~cm}$ ）として 初めて記録され，その後 2009 年 7 月 6 日および 2014 年 6 月 15 日に再捕獲された。 また，No. 5 の個体は，2000年 11 月 19 日に江田島湾で漁網により成体メス（前体幅長 $26.0 \mathrm{~cm}$ ）として初めて記録され，その後 2001 年 11 月 10 日に再び湾内で漁網に掛かったところを確認され，最後に 2004 年 11 月 10 日に江田島小学校護岸に流れついた死骸 として記録されていた。

カブトガニの繁殖状況について, 調査期間中, カブトガ 二の来遊つがい，もしくは産卵を確認できたのは，2000 年 7 月 31 日（夜）の 1 回のみであり, 他の調査日ではい ずれも確認されなかった（Table 3).

\section{竹原市における生息状況}

2015 年，2016 年の調査によって出現個体の時期，脱皮 齢，生息密度などの知見が明らかになった。2016 年 4 月 において 46 個体の幼体, 2015 年 7 月には成体雌雄つがい 1 組, 2016 年 7〜8 月には成体雌雄つがい 2 組と単独成体 メス 1 個体が確認されるに至る。2015 年 7 月 31 日，雌雄 つがい 1 組は河口から約 $200 \mathrm{~m}$ 離れたコアマモの繁茂す る泥場で発見された。 2016 年 7 月 21 日, 8 月 5 日に確認 された雌雄つがい 2 組はアマモが茂る潮間帯下部（河口か ら約 $330 \mathrm{~m}$ ）と幼体が生息する潮間帯の比較的上部（河口 から約 $100 \mathrm{~m}$ ）から発見された。単独成体メスは2016年
Table 2. Recaptured data of tri-spine horseshoe crab Tachypleus tridentatus at Etajima City.

\begin{tabular}{|c|c|c|c|c|}
\hline $\begin{array}{c}\text { Individual } \\
\text { Number }\end{array}$ & $\begin{array}{c}\text { Collection } \\
\text { date }\end{array}$ & $\begin{array}{l}\text { Carapace } \\
\text { width } \\
(\mathrm{cm}) \text { sex }\end{array}$ & Collecting zone & Notes \\
\hline \multirow[t]{3}{*}{ No. 5} & 20001119 & 26.0 우 & Offshore of Etajima Bay & \\
\hline & 20011110 & & Offshore of Etajima Bay & \\
\hline & 20041110 & & Offshore of Etajima Bay & Dead specimen \\
\hline \multirow[t]{4}{*}{ No. 6} & 20010319 & $23.00^{\pi}$ & Offshore of Etajima Bay & \\
\hline & 0606 & & Offshore of Etajima Bay & \\
\hline & 1013 & & Offshore of Etajima Bay & \\
\hline & 20020628 & & Offshore of Etajima Bay & \\
\hline \multirow[t]{3}{*}{ No. 7} & 20010515 & $24.4 \sigma^{\pi}$ & Offshore of Etajima Bay & \\
\hline & 0901 & & Offshore of Etajima Bay & \\
\hline & 20020707 & & Offshore of Etajima Bay & \\
\hline \multirow[t]{2}{*}{ No. 12} & 20050722 & 24.7 우 & Offshore of Etajima Bay & \\
\hline & 1006 & & Offshore of Etajima Bay & \\
\hline \multirow[t]{2}{*}{ No. 16} & 20070501 & $23.00^{7}$ & Intertidal zone of Nagase & \\
\hline & 20080815 & & Offshore of Etajima Bay & \\
\hline \multirow{2}{*}{ No. 18} & 20070501 & 22.0 & Intertidal zone of Nagase & \\
\hline & 20080909 & & Intertidal zone of Nagase & Dead specimen \\
\hline \multirow[t]{5}{*}{ No. 20} & 20070501 & 19.0 & Intertidal zone of Nagase & \\
\hline & 20080507 & & Intertidal zone of Nagase & \\
\hline & 0604 & & Intertidal zone of Nagase & \\
\hline & 0605 & & Intertidal zone of Nagase & \\
\hline & 0703 & & Intertidal zone of Nagase & Dead specimen \\
\hline \multirow[t]{3}{*}{ No. 22} & 20070531 & 20.0 & Intertidal zone of Nagase & \\
\hline & 20080604 & & Intertidal zone of Nagase & \\
\hline & 0916 & & Intertidal zone of Nagase & Dead specimen \\
\hline \multirow[t]{2}{*}{ No. 26} & 20070811 & 23.0 & Intertidal zone of Nagase & Under exuviation \\
\hline & 20080521 & & Intertidal zone of Nagase & \\
\hline \multirow[t]{2}{*}{ No. 27} & 20070811 & 23.1 & Intertidal zone of Nagase & Under exuviation \\
\hline & 20090620 & & Intertidal zone of Nagase & \\
\hline \multirow[t]{3}{*}{ No. 29} & 20070829 & $24.00^{\pi}$ & Intertidal zone of Nagase & \\
\hline & 20090424 & & Intertidal zone of Nagase & \\
\hline & 20111125 & & Offshore of Etajima Bay & \\
\hline \multirow[t]{3}{*}{ No. 30} & 20070829 & $24.00^{x}$ & Intertidal zone of Nagase & \\
\hline & 20080701 & & Intertidal zone of Nagase & \\
\hline & 20111003 & & Offshore of Etajima Bay & \\
\hline \multirow[t]{3}{*}{ No. 37} & 20070927 & $23.0 \sigma^{7}$ & Intertidal zone of Nagase & \\
\hline & 20090706 & & Intertidal zone of Nagase & \\
\hline & 20140615 & & Intertidal zone of Nagase & Dead specimen \\
\hline \multirow[t]{2}{*}{ No. 43} & 20080526 & $22.60^{7}$ & Offshore of Etajima Bay & \\
\hline & 0620 & & Intertidal zone of Nagase & \\
\hline \multirow[t]{2}{*}{ No. 50} & 20080605 & $22.80^{7}$ & Intertidal zone of Nagase & \\
\hline & 0830 & & Intertidal zone of Nagase & \\
\hline \multirow[t]{2}{*}{ No. 57} & 20080620 & $22.80^{7}$ & Intertidal zone of Nagase & \\
\hline & 0830 & & Intertidal zone of Nagase & \\
\hline \multirow[t]{2}{*}{ No. 65} & 20080716 & 21.7 & Intertidal zone of Nagase & \\
\hline & 20091202 & & Offshore of Etajima Bay & \\
\hline \multirow[t]{2}{*}{ No. 66} & 20080716 & 22.7 & Intertidal zone of Nagase & \\
\hline & 20090709 & & Intertidal zone of Nagase & \\
\hline \multirow[t]{3}{*}{ No. 68} & 20080829 & $23.30^{7}$ & Intertidal zone of Nagase & \\
\hline & 20090527 & & Intertidal zone of Nagase & \\
\hline & 0904 & & Offshore of Etajima Bay & \\
\hline \multirow[t]{3}{*}{ No. 70} & 20090427 & $24.5 \sigma^{7}$ & Intertidal zone of Nagase & \\
\hline & 0818 & & Intertidal zone of Nagase & \\
\hline & 20110103 & & Offshore of Etajima Bay & Dead specimen \\
\hline
\end{tabular}

8月 5 日にアマモが茂る潮間帯下部（河口から約 $290 \mathrm{~m} ）$ で発見された。

2015 年 9 月に記録したカブトガニの成長段階組成，生 息密度などのデータは以下のようである. 幼体は河口東西 周辺の干潟に集中しており, 沖合のアマモ場などでは確認 することができなかった。2015 年 9 月 13，14 両日に調査 
Table 3. Records of reproductive activity of the horseshoe crab observed in intertidal zone of Nagase and Kounan, Etajima Island.

\begin{tabular}{cccc}
\hline Collection year & $\begin{array}{c}\text { Total number } \\
\text { of investiga- } \\
\text { tions }\end{array}$ & $\begin{array}{c}\text { Mean number } \\
\text { of investigators }\end{array}$ & $\begin{array}{c}\text { Number of } \\
\text { pairs }\end{array}$ \\
\hline 2000 & 4 & 13 & 1 \\
2001 & 11 & 6 & 0 \\
2002 & 7 & 3 & 0 \\
2003 & 4 & 4 & 0 \\
2004 & 3 & 1 & 0 \\
2005 & 7 & 1 & 0 \\
2006 & 0 & 0 & 0 \\
2007 & 2 & 4 & 0 \\
2008 & 7 & 2 & 0 \\
2009 & 2 & 2 & 0 \\
2010 & 1 & 3 & 0 \\
2011 & 1 & 2 & 0 \\
2012 & 2 & 2 & 0 \\
2013 & 1 & 2 & 0 \\
2014 & 2 & 2 & 0 \\
2015 & 1 & 2 & 0 \\
2016 & 7 & 2 & 0 \\
\hline
\end{tabular}

した結果では賀茂川河口東西のおおよそ $60 \times 60=3,600 \mathrm{~m}^{2}$ の潮溜まりのある範囲にそれぞれ幼体が東側 21 個体, 西 側 18 個体確認されたので, 密度は 0.58 個体 $/ 100 \mathrm{~m}^{2}, 0.50$ 個体 $/ 100 \mathrm{~m}^{2}$ であった。 また，この調査時に捕獲したカブ トガニ幼体の前体幅長, 湿重量組成を Figs. 4,5 に示す. 最小前体幅長は $2.03 \mathrm{~cm}$, 最大前体幅長は $5.05 \mathrm{~cm}$, 平均

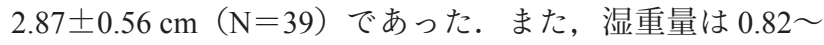
$10.34 \mathrm{~g}$ の範囲であり, 平均は $2.43 \pm 1.64 \mathrm{~g} （ \mathrm{~N}=39 ）$ で あった。 2015 年 7 月 31 日に観察された成体雌雄 1 つがい についてはサイズを正確には計測していないが，ほぼ完全 に掘り出したオスは全長約 $50 \mathrm{~cm}$ 以上に達し, 完全に泥か ら掘り出さなかったメスはさらに大型であった。

2016 年 2 月 25 日干潮時（1530～1630）に同場所をくま なく調査したが, 幼体, 成体ともに底質表面上には発見で きなかった。

2016 年 4 月 22 日には干潟において幼体が再び発見され


口東側の潮溜まりのある範囲 $\left(2,118.2 \mathrm{~m}^{2}\right)$ に 29 個体, 西 側 $\left(79.1 \mathrm{~m}^{2}\right)$ で 14 個体発見することができた。このため, 生息密度はそれぞれ 1.37 個体 $/ 100 \mathrm{~m}^{2}, 2.06$ 個体 $/ 100 \mathrm{~m}^{2}$ と なった。これら幼体が生息している 2 箇所の底質表面付近 の中央粒径值は $0.15 \mathrm{~mm}$ および $0.27 \mathrm{~mm}$ であった. 2016 年 4 月に捕獲したカブトガニ幼体の前体幅長, 湿重量の組 成を Figs. 4, 5 に示す. 生息密度を算出した潮溜まりから 数十 $\mathrm{m}$ 離れた場所から発見された 3 個体も含めた全 46 個 体の最小前体幅長は $1.60 \mathrm{~cm}$, 最大前体幅長は $5.22 \mathrm{~cm}$, 平 均 $3.36 \pm 0.93 \mathrm{~cm}$ であった。 また, 湿重量は $0.30 \sim 12.05 \mathrm{~g}$ の範囲であり, 平均は $4.09 \pm 2.47 \mathrm{~g}(\mathrm{~N}=46)$ であった. 2015 年 9 月に捕獲した個体と比較して前体幅長, 湿重量 ともに増加している（前体幅長 : $U$ 值 $=560.0$, 湿重量 : $U$
值 $=552.5, p<0.01)$. また, 成長段階の組成についても 2015 年 9 月と 2016 年 4 月では異なり（ $\chi^{2}$ 值 $=32.6$, d.f. $=$ 6, $p<0.01), 2016$ 年 4 月に観察したカブトガニでは 2015 年 9 月に比べて， 7 脱皮齢の割合が低く，8，9 脱皮齢の割 合が高くなった（残差分析， $p<0.05$ ）。2016 年 7 月 21 日， 8 月 5 日にそれぞれ成体雌雄 1 つがいが発見された。これ らの前体幅長（前者：メス $23.6 \mathrm{~cm}$, オス $20.6 \mathrm{~cm}$; 後者 : メス $27.1 \mathrm{~cm}$ ，オス $20.7 \mathrm{~cm}$ ）であった 2016 年 8 月 5 日に 発見された単独成体メスの前体幅長は $23.3 \mathrm{~cm}$ であった. また，後者のメスにはカニエラエボシ Octolasmis cf. neptu$n i$ (MacDonald, 1869)（遊佐 私信）の外部共生が見られた. さらに, 後者のつがい両個体の前体部腹側, 歩脚基部, 蓋 板裏側からカブトガニウズムシ Ectoplana limuli (Ijima \& Kaburaki, 1916）が多数発見された.

\section{竹原市の個体群の遺伝的特徵}

本研究で得られた竹原市八チ干潟の個体群では, 解析し た 10 個体全てが瀬戸内海西部に優占的にみられるハプロ タイプ AT1（Nishida \& Koike 2009）を持つことが明らかと なった. なお，計 10 個体から得られた塩基配列は GenBank accession numbers: MF511092-MF511101 として国際塩基配 列データベース（INSD）に登録された。

\section{考察}

\section{江田島市における生息状況}

江田島では，1999～2016 年の調査期間に合計 77 個体の カブトガニを確認した。確認された個体数は, 2006 年ま での期間には 0 4 個体/年であったが，2007 年と 2008 年 にはそれぞれ 23 個体/年および 31 個体/年と多くなり, 2009２016 年は 0〜3 個体/年と少なくなっていた。笠岡 湾における調査によると, カブトガニは孵化後に浮遊期を 持たず，成体の行動範囲はほとんどの場合，湾周辺の $5 \mathrm{~km}$ の範囲内にあるとされている（䊍路 2015）. 後述す るように江田島湾での標識放流調査において, 再捕獲情報 はすべて湾内からのものであり，湾外からの記録はなかっ た。加えて著者らの知る限り, 本調査開始以降に他海域か らの人為的なカブトガニの移入情報もない.これらのこと を考慮すると, 江田島湾のカブトガニの個体数変動は, 湾 内外からの移出入による影響の可能性は低く，湾内におけ る産卵とその後の生残が影響していると考えられる。ま た，1999〜2016 年の調査期間中にカブトガニの来遊つが い,もしくは産卵を確認できたのは, 2000 年 7 月の 1 回 のみであった。他海域の年間来遊つがい数は, 福岡県津屋 崎沿岸（2005～2008 年）の 40～139 つがい（和田ら 2010）, 福岡県曽根干潟（1995～2013 年）の 24〜1,581 つがい（林 2015）と報告されており，江田島湾における繁殖状況は, 加入という観点からみると危うい状況にあることが示唆さ れる. 他地域と比べて調查回数の不足は否めないが, 江田 
島湾内の確認個体数が 2007 年と 2008 年を除くと 0 4 個 体/年と少ないことや再捕獲個体を含んでいること, さら には 2007 年および 2008 年に多くの個体を確認することが できた長瀬海岸（定点調査場所）において, ここ数年, 個 体を確認できていないことなどを考えると, 現在の湾内に 生息するカブトガニの個体数は極めて少ないと推測される.

惣路（2015）の室内飼育の記録によると, カブトガニの 成長は, オスの場合 13 年で 15 回の脱皮をして 16 脱皮齢 で成体になり，メスの場合 14 年で 16 回の脱皮をして 17 脱皮齢で成体になるとされている．江田島湾で確認された カブトガニの成長段階別の脱皮齢数と体サイズの関係をみ ると，15脱皮齢までの幼体 23 個体（前体幅長：3.5 $21.0 \mathrm{~cm}$ ), 16 脱皮齢幼体 17 個体（前体幅長：21.5 $24.7 \mathrm{~cm}$ ）および成体オス（16脱皮齢）29個体（前体幅 長：21.0 25.0 cm)，成体メス（17脱皮齢）8個体（前体 幅長：24.0～26.5 cm）に区分された。このようにメスはオ スよりも最終脱皮までの脱皮回数が 1 回多いため（牢路 2015)，16脱皮齢幼体と成体オス（16 脱皮齢）の前体幅長 の範囲と重複する現象が起こるが，16脱皮齢幼体は最終 脱皮後に成体メスになるものと推測された。なお，16脱 皮齢幼体の最大前体幅長個体（No. $32 ：$ 前体幅長 $24.7 \mathrm{~cm}$ ) は 16 脱皮齢幼体の中でも比較的大型の個体であるため, 成体メスの小型個体（Nos. 11，75：前体幅長 $24.0 \mathrm{~cm}$, No. 12 ：前体幅長 $24.7 \mathrm{~cm} ） と$ 前体幅長が逆転または重複する 現象が起きている。また，2007〜2008 年に確認された $10 \sim 13$ 脱皮齢の 3 個体は, 孵化後 7〜 10 年の個体と推定 されており，2000年 7 月の産卵後に孵化して成長した幼 体である可能性が高い. 2013 年の干潟調査により確認さ れた 8 脱皮齢の 1 個体は, 孵化後 4 6 年の大きさである ことから, 2000 年以降も江田島湾内で産卵が行われたこ とを示唆するものである。したがって，今回の調査期間中 に確認されたカブトガニは，15～16 脱皮龃幼体・成体の 世代（1990 年代後半産），10～13 脱皮齢幼体の世代（2000 年代前半産), 8 脱皮齢幼体の世代 (2000 年代後半産), 少 なくとも 3 つの異なる時期に産卵・孵化した個体群が含ま れる可能性が示唆された.

本調査において, 標識を貼り付けて再び江田島湾に放流 されたカブトガニ 74 個体の中で, 20 個体が湾内で再捕獲 された. 最も再捕獲された期間が長かったNo. 37 の個体 は, 2007 年 9 月に長瀬干潟で成体オスとして初めて記録 され，その後 2009 年 7 月および 2014 年 6 月に再捕獲され た.したがって, カブトガニは最終脱皮を終えて成体に なってから少なくとも 7 年は生存していることがわかっ た.カブトガニの成体がどの程度生残できるかについては 情報が少ない，伊万里湾における成体の標識調査によって 3 年は生存することが確認されている（関口 1991）。寿命 は数十年とも言われているが, 科学的根拠に乏しい（日野 2008). 今後, 寿命と総産卵回数や総産卵数などに関連す る調査がなされるべきである.
カブトガニの生活史について，潮間帯で産卵後に孵化し た幼生は，脱皮を繰り返しながら前体幅長 $7 \mathrm{~cm}$ になる幼 体まで成長し, その後は生活場所を潮下帯へ移動させるこ と，および最終脱皮齢に近い幼体や成体は水温 $18^{\circ} \mathrm{C}$ 以上に なると浅場へと移動し始めると考えられている（関口 1984; 川原 1982，1984）。また，笠岡湾におけるカブトガニ成体に ロガーを装着した行動追跡調査によると, 10 月または 11 月から 5 月の間は水深 $10 \mathrm{~m}$ 未満の浅海底で休眠すること が明らかになっている（牢路 2015）。江田島湾において, 少なくとも 13 脱皮齢以上のカブトガニは， 5 月下旬には干 潟で確認できるようになり，10月以降は生体や死骸，脱皮 殼のいずれも確認できなくなることや, 標識放流個体の再 捕獲情報が湾の沖合では 5〜 7月および 9〜11月，干潟で は 5〜8月に集中していたことから，定点調査地である長 瀬干潟でみられたカブトガニの挙動変化は, 関口（1984） および川原 $(1982,1984)$ によって示唆されている成長段階 による生息場所の変化を示したものかもしれない.

\section{竹原市における生息状況}

本調査によって竹原市八チ干潟では 4 10 脱皮齢カブト ガニ幼体が発見されたことから産卵がここ数年連続して行 われていると推測できる。 八チ干潟で発見された最長齢の 10 脱皮齢は 5 歳齢と推測されているので（川原 1982; 和 田ら 2008)，2011 年以降に産卵が連続して行われていたと 推定される.

本調査以前の生息状況については過去の文献である程度 判明した。竹原市では，カブトガニの成体は 1950～1960 年代には多産し, 1970 年代には激減したことが清瀬



Fig. 4. Relationships between carapace widths and instars of individuals of the tri-spine horseshoe crab Tachypleus tridentatus collected from Hachi Estuary at Takehara City, Hiroshima Prefecture on 13, 14 September 2015 (upper) and 22 April 2016 (lower). Instars defined by Sekiguchi (1984). 




Fig. 5. Relationships between wet weight and instars of individuals of the tri-spine horseshoe crab Tachypleus tridentatus collected from Hachi Estuary at Takehara City, Hiroshima Prefecture on 13, 14 September 2015 (upper) and 22 April 2016 (lower). Instars defined by Sekiguchi (1984).

（1994）によって明らかになっている.1980 年代は比較的 安定していた（清瀬 1994）。八チ干潟より約 $3 \mathrm{~km}$ 西方に 位置し，以前から産卵場になっていることが指摘されてい た吉名町では 1993 年に産卵が確認され，1998 年には全長 $5 \mathrm{~cm}$ の幼体（7 脱皮齢）が発見されており（中国新聞 1998）， さらに筆頭著者らも 2001 年 6 月 23 日，幼体複数個体を同 所で確認している（大塚・森廣 未発表）。また，1993年 以降（年代特定できず），八チ干潟〜吉名の沖合ではさし 網に多くの成体が掛かっていたと漁師の証言があり, 竹原 市沖合にある生野島，大崎上島でも生息していたという (湯浅 1993). 最近では，八チ干潟では 2005 年に成体雌雄 つがいが市民によって発見されたが（八チ干潟調査隊 2016），その後しばらく出現記録は途絶えた。再度，2013 年 10 月に幼体発見の記録がある（Oh! すばらしい企画 2016).

本調査に打ける八チ干潟に出現した幼体は, 関口 （1984）に従うと，2015 年 9 月は 5 9 脱皮齢，2016 年 4 月は 4 10 脱皮齢（Figs. 4, 5）に相当する. 八チ干潟では 冬眠前後を比較すると前体幅長, 湿重量ともに後者が増加 しており (Figs. 4, 5 参照), 越冬から目覚めた直後から摂 食して脱皮, 成長が開始されると推定される.八千干潟に おける幼体および成体つがいの季節的出現は九州の杵築湾 (川原 1982, 1984), 津屋崎干潟（和田ら 2008）, 曽根干潟 （林 2015）での野外観察結果とょく一致する。つまり，幼 体は春〜秋に干潟の底質表面上に出現し, 成体つがいは 7 〜8 月に干潟に産卵のために出現するというパターンであ る. また, 冬には成体は江田島市同様に潮下帯に移動, 幼
体は底質中に埋没して越冬すると考えられる. 竹原市周辺 の海表面水温は最低約 $10^{\circ} \mathrm{C}$ なの゙゙ $10 \sim 15^{\circ} \mathrm{C}$ 以下では幼体 は底質中に潜りこんでいると考えられる。

今回の八チ干潟の調査において, 幼体が分布する場所の 底質の中央粒径值は $0.15 \mathrm{~mm}$ および $0.27 \mathrm{~mm}$ であった。 この值は, 曽根干潟において幼体を観測した地点での 1995 年 2013 年の間の平均中央粒径值 $0.067 \mathrm{~mm}$ （自然環 境定量評価研究会 2014）と比較するとやや粗い. 大分県 守江湾においてカブトガニの成体の産卵に適した底質の中 央粒径值のレンジは $0.4 \sim 1.0 \mathrm{~mm}$, 平均 $0.7 \mathrm{~mm}$ と判明し ている (清野ら 2000). したがって, カブトガニの成体が 産卵し,さらに幼体が生育する干潟には幅広い粒径を持っ た底質が必要であることがわかる。

カブトガニが日本各地で絶滅危惧種と選定されているの で, 宿主特異性の高いカブトガニウズムシも岡山県, 福岡 県では同様に絶滅危惧種とされている（岡山県 2009; 福岡 県 2014)。竹原市八チ干潟における今回の調査では, 本種 はカブトガニ幼体には全く寄生が見られず，成体のみに寄 生が確認された。 今後, 生物多様性保全の観点から宿主の 成長段階別に寄生状況や生活史の詳細なデータを収集する 必要がある。

\section{竹原市の個体群の遺伝的特徵}

Nishida \& Koike（2009）による日本産カブトガニのミト コンドリア遺伝子 AT リッチ反復配列部分の解析の結果, ハプロタイプ多様性は九州西岸で最も高く, 瀬戸内海西部 に位置する山口湾, 和間干潟では低いことを明らかにし た. 広島県, 岡山県の個体群はさらに瀬戸内海中央部に生 息しているため, 遺伝的多様性は瀬戸内海西部の個体群と 類似すると推測される。実際に，本研究で得られた竹原市 八チ干潟の個体群では, 解析した 10 個体全てが瀬戸内海 西部 2 地点に優占的にみられるハプロタイプ（AT1： Nishida \& Koike 2009 参照）を持つことが明らかとなった. これは, 祖先集団の一部が地質学的には比較的最近の完新 世になって九州北部から瀬戸内海に進出していったという Nishida \& Koike（2009）の仮説（創始者効果）とは矛盾し ない結果となった.

本研究では 10 個体の遺伝子配列を決定したが，これは Nishida \& Koike (2009) の解析で用いられた一地点ごとの個 体数（7～69）と比較してもサンプルサイズが著しく少ない わけではない. 今後, 広島県竹原市八チ干潟産のカブトガ 二について追加の遺伝子解析を行うとともに, 八チ干潟よ りも東部に生息する個体あるいは過去に生息した天然個体 群の標本の遺伝子解析が行われることによって, 日本産力 ブトガニの生物地理がより明らかになると期待される。

\section{ま と め}

今回の広島県におけるカブトガニ調査によって，(1) 近年 
の新規加入そしておそらく産卵活動は竹原市八チ干潟で明 確であるものの, 産卵つがいは毎年数ペアという小規模で あること，（2）江田島市では幼体が極めて少ない事から産 卵, 新規加入は稀か全く起こっていない状態と推測される.

広島県の生息地のみならず西日本に産するカブトガニの 保全は喫緊の課題である. 地域個体群の絶滅を防ぐために は, カブトガニの生息状況のモニタリングを継続すること はもとより, 全成長段階の生息環境, 行動, 生殖などに関 する長期的な科学的データの蓄積, さらにそれに基づく公 的法規制の施行が必要であろう。もう1つの柱としては研 究者, 一般市民, 保護団体, 行政者が連携, 一致結束して 息の長い保全活動を実施していくことであり，関口 （1993）が強調するように生息地周辺の住民の保全に対す る熱意が最も重要である.

謝辞 : 本研究は公益財団法人福武財団「瀬戸内海文化研究・活 動支援助成」によって行われたのでここに感謝を記す。本研究は 笠岡市立カブトガニ博物館惣路紀通氏, 福山大学渡辺伸一准教 授, 日本カブトガニを守る会福岡支部の林修氏, 高橋俊吾氏, 北 九州市立自然史 - 歴史博物館の武石全慈博士, 下村通誉博士, 九十九水族館の岩岡千香子氏, 長崎大学石松惊教授, 奈良女子大 学遊佐陽一教授など多くの方々の情報提供によって完成すること ができた。また，竹原市でのカブトガニ生息状況のアンケートに 協力くださった末森康明氏, 廿日出郁夫氏, 岡崎孝映氏, その他 匿名の方に対してここに謝意を表す。草稿に貴重なコメントをい ただいた鹿児島大学佐藤正典教授, 2 名の査読者の方にも心から 感謝申し上げる.

\section{引用文献}

Chan, B.K.K., R. E. Prabowo and K.-S. Lee 2009. Crustacean Fauna of Taiwan: Barnacles, Volume I-Cirripedia: Thoracica Excluding the Pyrgomatidae and Acastinae. National Taiwan University, Keelung, $297 \mathrm{pp}$.

中国経済産業局 2005. 平成 16 年度産業公害防止対策調査瀬戸内海 臨海部における水質・底質污濁防止及び環境浄化・修復技術手 法の検討調査，中国経済産業局，広島市， $142 \mathrm{pp}$.

中国新聞 1998.「竹原もカブトガニ繁殖地」.（1998 年 5 月 11 日掲 載)

中国新聞「新せとうち学」取材班 1998. 海からの伝言一新せとう ち学一, 中国新聞社, 広島市, $127 \mathrm{pp}$.

愛媛県 2014. 愛媛県レッドデータブック. 愛媛県の絶滅のおそれ のある野生生物. http://www.pref.ehime.jp/reddatabook2014/top.html （2016 年 5 月 13 日閲覧）

福岡県 2014. 福岡県レッドデータブック 2014 (改訂版). http:// www.fihes.pref.fukuoka.jp/ kankyouseibutsu/rdb/rdb.html（2016 年 5 月 13 日閲覧)

八チ干潟調查隊 2016. http://www.geocities.jp/pipipopo227/index.html (2016 年 5 月 13 日閲覧)

林 修 2015. 1995 年〜2013 年曽根干潟カブトガニ産卵調査の記 録, 自費出版, $188 \mathrm{pp}$.

日野明日香 2008. 絶滅危惧海生生物種保護に関する一考察一カブ トガニ保護を事例として一. 海洋政策研究, 6: 49-68.

平山良太・西原直久 2008. 能美町長瀬海岸干潟におけるカブトガ 二の生息状況について. 大杮自然環境体験学習交流館報, 3 : 5-16.

平山良太・西原直久 2009. 能美町長瀬海岸干潟におけるカブトガ
二の生息状況について（2）。柿自然環境体験学習交流館報, 4: 5-13.

広島県 1995. 広島県の絶滅のおそれのある野生生物. レッドデー タブックひろしま, 広島県, $437 \mathrm{pp}$.

広島県 2004. 改訂・広島県の絶滅のおそれのある野生生物.レッ ドデータブックひろしま 2003, 広島県, 515 pp.

広島県 2012. 広島県の絶滅のおそれのある野生生物 (第 3 版). レッドデータブックひろしま 2011 , 広島県, $633 \mathrm{pp}$.

伊藤剛史・伊藤大吾 2009. 歴史の中のカブトガニ. 古文書でたど るカブトガニ, サイエンスハウス, 東京, $186 \mathrm{pp}$.

加藤 真 1999. 日本の渚一失われてゆく海辺の自然一, 岩波書店, 東京, $220 \mathrm{pp}$.

環境省 2015. 環境省レッドリスト 2015. その他無脊椎動物. http:// www.env.go.jp/press/files/jp/28074.pdf（2017 年3月 14 日閲覧）

Kawabata, S., T. Koshiba and T. Shibata 2009. The lipopolysaccharideactivated innate immune response network of the horseshoe crab. Invertebrate Survival Journal, 6: 59-77.

川原 大 1982. カブトガニ幼生の生態調査. 海洋と生物, 4: 380382.

川原 大 1984. カブトガニの成長と日周期性の変化. 動物と自然, 14: 22-26.

清瀬祥三 1994. 瀬戸内海リゾート構想からカブトガニ, 八クセン シオマネキなどの希少な野生生物の生息地を守る運動. 日教組 第 43 次教育研究全国集会報告書, 34: 4-9.

前田耕作・清野聡子・西原繁朝・日野明日香 2000. カブトガニ Tachypleus tridentatus (Leach) の孵化幼生の生態と物理環境との 関連. 日本ベントス学会誌, 55: 15-24.

長崎県 2011. 長崎県レッドリスト. https://www.pref.nagasaki.jp/ bunrui/kurashi-kankyo/shizenkankyo-doshokubutsu/rarespecies/ reddata/68122.html（2016 年 5 月 13 日閲覧）

日本ベントス学会 (編) 2012. 干潟の絶滅危惧動物図鑑. 海岸ベン トスのレッドデータブック, 東海大学出版会, 東京, $285 \mathrm{pp}$.

西原直久 2007. 江田島湾に生息するカブトガニ Tachypleus tridentatus について。大柿自然環境体験学習交流館報，2: 5-20.

Nishida, S and H. Koike 2009. Genetic structure of Japanese populations of Tachypleus tridentatus by mtDNA AT-rich region sequence analysis. In Biology and Conservation of Horseshoe Crabs, Tanacredi, J. T., M. L. Botton and D. Smith (eds.), Springer, Dorddrecht, pp. 183-196. 西村三郎（編著）1995. 原色検索日本海岸動物図鑑［II］，保育社， 大阪市, $663 \mathrm{pp}$.

信田紗希・神野有生・山本浩一・田中陽二・関根雅彦 2012. 山口 湾における 3 次元流動モデルの構築と浮遊幼生の輸送特性に関 する数值実験. 土木学会論文集 G (環境)，68: III_297-III_305.

Oh!すばらしい企画 2016. http://housyanou28.seesaa.net/article/ 376674874.html（2016 年 5 月 13 日閲覧）

岡山県 2009. 岡山県版レッドデータブック 2009. http://www.pref. okayama.jp/seikatsu/sizen/reddatabook/（2016 年 5 月 13 日）

清野聡子 2001. カブトガニの形態・生態と流れの関係. ながれ, 20: $365-374$.

清野聡子 - 足利由紀子 - 山下博由 - 土屋康文 - 花輪伸一 2002. 大 分県中津干潟における市民計画型干潟生物調査と海岸環境保全 策の提案. 海洋工学論文集, 49: 1136-1140.

清野聡子 - 前田耕作 - 日野明日香 - 宇多高明 - 真間修一 ・山田伸 雄 1998a. カブトガニは何故その岸辺に産卵するのか? 一産卵地 の地形・堆積物・波・流れの特性一. 海岸工学論文集, 45; 1091-1095.

清野聡子・宇多高明 2001. カブトガニ産卵地造成ミティゲーショ ン手法に係わる指針案の提案. 海洋工学論文集, 48: 1381-1385. 清野聡子・宇多高明・足利由紀子・神田康嗣・和田太一・城野博 之 2007. 干潟縁辺部における砂州で囲まれた塩性湿地の生物環 境条件. 海洋工学論文集, 54: 1271-1275.

清野聡子. 宇多高明・真間修一・波俊郎・芹沢真澄・古池 鋼・前田耕作・日野明日香 1998b. 絶滅危惧生物カブトガニの生 
息地として見た守江湾干潟の地形・波浪特性. 海岸工学論文 集, 45: 1096-1100.

清野聡子・宇多高明・土屋康文・前田耕作・三波俊郎 2000. カブ トガニ産卵地の地形特性と孵化幼生の分散観測一希少生物生息 地のミティゲーション計画のために一。応用生態工学, 3:7-19. 清野聡子・宇多高明・佐藤㯖司・鳥居謙一・加藤史訓・笛田俊 治・丸山 準 2004. 自然共生型海岸づくりにおける希少生物生 息地の生態工学的保全手法. 海岸工学論文集, 51: 1341-1345.

清野聡子 - 土屋康文・ O'Dor, R. - 宇多高明・西原繁朝 - 釘宮浩 三・渡辺憲隆 1999. 電波超音波ブイ型バイオテメトリーシステ ムによるカブトガニの行動モニタリング．海岸工学論文集，46: 1296-1300

関口晃一 1984. カブトガニの生物学, サイエンスハウス, 東京, $346 \mathrm{pp}$.

関口晃一 1991. カブトガニの不思議一「生きている化石」は警告 する一, 岩波書店, 東京, $229 \mathrm{pp}$.

関口晃一 1993. 日本のカブトガニの現況 (増補版), 日本カブトガ 二を守る会, 岡山, $229 \mathrm{pp}$.

自然環境定量評価研究会 2014. 曾根干潟における貴重種の特定と 保護・保全活動。平成 25 年度活動報告書, $49 \mathrm{pp}$.

䊍路紀通 2015. カブトガニの謎. 2 億年前から形を変えずに生き 続けたわけ，誠文堂新光社，東京， $143 \mathrm{pp}$.

竹原市 2015. 第 2 章 竹原市の維持及び向上すべき歴史的風致.
竹原市歴史的通知維持向上計画. 竹原市, pp. 40-106.

和田恵次 - 西平守孝 風呂田利夫 - 野島 哲 - 山西良平 - 西川輝 昭・五嶋聖治・鈴木孝男 - 加藤 真 - 島村賢正・福田 宏 1996. 日本における干潟海岸とそこに生息する底生生物の現状. WWF Japan Science Report, 3: 1-181.

和田年史・板谷晋嗣・秀野真理 2010. 福岡県津屋崎沿岸における カブトガニの産卵場所および来浜ペア数の年変動. 保全生態学 研究, 15: 163-171.

Wada, T., T. Mitsushio, S. Inoue. H. Koike and R. Kawabe 2016. Movement patterns and residency of critically endangered horseshoe crab Tachypleus tridentatus in a semi-enclosed bay determined using acoustic telemetry. Plos ONE. Doi: 10.1371/journal.pone.0147429

和田年史 - 米山太平 - 橋口大佑 - 野村俊介 - 板谷晋嗣 - 秀野真理 2008. 福岡県津屋崎干潟におけるカブトガニ幼生の成長とモ二 タリング手法の開発. 保全生態学研究, 13: 199-205.

渡辺伸一 2014. 絶滅危惧種カブトガニをキーストーン種とした沿 岸生態系の保全. 科学研究費助成事業研究報告書, 4 pp.

渡辺伸一・片山統貴・野本智也 2013 . 水中撮影による飼育動物の 行動評価：カブトガニ類の活動率と利用場所の推定. 福山大学 内海生物資源研究所報告, 23: 1-6.

湯浅一郎 1993. ヒロシマにカブトガニの生息地. 技術と人間, 22 : $58-66$. 